pp. $94-108$

\title{
Exploring the Trend of Czech FDIs and their Effect to Institutional Environment
}

\author{
Submitted 18/11/19, $1^{\text {st }}$ revision $23 / 12 / 19,2^{\text {nd }}$ revision 07/01/20 accepted 02/02/20
}

\author{
Irena Jindřichovská ${ }^{1}$, Erginbay Ugurlu ${ }^{2}$, Eleftherios I. Thalassinos ${ }^{3}$ \\ Abstract:
}

Purpose: The goal of this paper is to explore the trend of FDIs in the Czech Republic and its changes in recent years using the gravity model. Apart from traditional variables used in FDI models we also introduce IFRS in national accounting rules.

Design/Methodology/Approach: We use open-source data from the World Bank and FDI data from the Czech national bank, to analyse a panel data of bilateral FDI for 19 EU countries over the period 2008-2017 by PPML specification.

Findings: We have observed significant effect of positive impact on broader introduction of IFRS in 2010 in terms of country imports and exports. We observed lower significance of IFRS dummy in the gravity model, where dependent variable is the sum of FDI inflow and FDI outflow it is not significant in the models which dependent variables are FDI inward and FDI outward for FDIs.

Practical Implications: In general, FDIs increased productivity in the Czech Republic, especially in 1990s. We assess the effect and possible contribution of traditional variables like size, GDP, border and distance to Czech FDIs.

Originality/Value: We find that the positive effect of IFRS exists at 10 percent significance for FDIs. Nevertheless we claim that this effect is mixed with other institutional issues, namely institutional isomorphism. Further tests will be needed after the forthcoming change of the Czech accounting act, which is approaching after 2020.

Keywords: PPML Estimation, FDI, IFRS, institutional isomorphism.

JEL codes: B23, F21, M 41, M48.

Paper type: Research article.

Acknowledgments: This paper is the result of Metropolitan University Prague research project no. 68-02 "Territorial Studies, Economics, International Relations" (2019) based on a grant from the Institutional Fund for the Long-term Strategic Development of Research Organisations. The authors would like to thank for useful comments and suggestions professors and participants of the 7th edition of the Conference IFRS Global Rules and Local Use - Beyond the Numbers in Prague 2019 and participants at conference ICABE 2019 in Thessaloniki Greece.

${ }^{l}$ Corresponding author, Metropolitan University Prague - Prague, Dean, Department of International Business, irena.jindrichovska@mup.cz

${ }^{2}$ Istanbul Aydin University-Istanbul, Head, Department of International Trade, erginbayugurlu@aydin.edu.tr

${ }^{3}$ Prof. University of Pireus and Aff. Prof. University of Malta, thalassinos@ersj.eu 


\section{Introduction}

Empirical results show that foreign direct investment abroad stimulates the growth of exports from countries of origin, and consequently, this investment is complementary to trade (Fontagné, 1999). Foreign direct investments are understood to support the growth of countries. Research on the relationship between IFRS and foreign direct investment has been performed in many economies, e.g. Gordon, Loeb, and Zhu (2012), Márquez-Ramos (2011), Okpala (2012), Efobi, Nnadi, Odebiyi and Beecroft (2014) and Chen, Ding and Xu (2014). Similar conclusions were found in studies concentrating on Eastern Europe Albu and Albu (2014), Lungu, Caraiani, and Dascălu (2017). In this context, it is assumed that one of influences of IFRS in Czech Republic is the attraction of FDIs.

In the Czech Republic, which is part of Eastern Europe, the relation was more challenging to establish empirically due to the weak capital market, which does not allow measuring the effect directly. Only 11 shares are listed on the Prague Stock Exchange as of 27.8.2019. Therefore, we establish that the influence of external factors and influence of institutional forces inspired and influenced through institutional isomorphism (DiMaggio Powel, 1983; 1991). We can observe gradual improvement over time as more and more companies are now using IFRS as their reporting standard. This is mostly motivated by trade relations with their clients or parents from other countries, where IFRS is used as accounting standard Prochazka (2017). In the Czech Republic intensive inflow of FDIs were observed namely in selected industries Szabo (2019). In these sectors there are also many subsidiaries of foreign companies increasing production and efficiency of Czech economy, see Prochazka (2018). Adopting internationally recognized rules and regulations is one of the key factors for better integration in the global economy and especially being part of the common Europe (Thalassinos and Stamatopoulos, 2015).

Therefore we claim that the pressure for IFRS adoption results from coercive, normative, and mimetic isomorphism. Coercive pressure comes from international institution such as World Bank and the International Monetary Fund (IMF) and World Trade Organization (WTO), normative pressures come from the accounting profession and mimetic pressures come from the desire to attract multinational corporations to the country and the desire to attract international partners for local entities, which was effectively happening in reality since the first part of 1990s.

This study shows that whether the IFRS stimulates foreign direct investment of the Czech Republic, by using panel data techniques. The data set of the paper consists of trade partners of the Czech Republic within the European Union.

\section{Literature Review}

International accounting standards contribute to positive changes in the institutional environment in the country, which affects the economic growth of countries 
Wysocki (2011), Gordon, Loeb and Zhu (2012) or Liu, Yao, Hu and Liu (2011). In general, this relation is valid across the globe; however the direct impact is sometimes difficult to measure especially in less developed economies with underdeveloped capital markets. In our study we concentrate on the link between trend of FDIs and changing institutional environment in the Czech Republic, one of the countries in Central and Eastern Europe, which has lately undergone many institutional changes e.g., Judge, Li and Pinsker (2010), Albu, (2013), Phan, Joshi and Mascitelli (2016), Thalassinos and Kiriazidis (2003), Thalassinos (2008) and Miteski and Stefanova (2017).

\subsection{Studies on FDI in the Czech Republic}

Coming from the general macroeconomic perspective, it is assumed that the contribution of FDI is an essential factor of the countries development. Alfaro, Chanda, Kalemli-Ozcan, and Sayek (2004) explored links among foreign direct investment (FDI), financial markets and economic growth. Their research came to conclusion that "FDI alone plays an ambiguous role in contributing to economic growth." However, "countries with well-developed financial markets gain significantly from FDI" see Alfaro, Chanda, Kalemli-Ozcan and Sayek (2004, p. 22). Babuněk (2012) explored the character of FDI in V4 countries and as a compact group using FDI per capita. The author found that there remain significant differences between the countries (MacGregor Pelikánová, 2019), especially when taking into consideration the nearest trading partners Germany and Austria.

Although there are many other contributing factors, mostly of institutional and conceptual nature (MacGregor Pelikánová, 2017), that the study did not take fully into consideration. Maitah, Hayat, Malec, and Eldeeb (2014) researched the impact of FDI on employment in the Czech Republic. The authors investigated long term relationship between FDI, GDP and host country employment on data form 19932011. The authors found that the major positive role is played by multinational companies, which use the appropriate economic incentives and convenient environment to FDI inflow. The effect of FDI inflow is observed mainly by an increase in GDP and employment will impact positively on capital investments thus money flow to country from outside will be increased (Uğurlu, 2010).

Several studies concentrate on positive FDI spillovers: e.g., Smarzynska (2004) explored the existence of positive spillovers initiated by FDIs initiated by presence of multinational firms and found that "firm productivity is positively correlated with the extent of potential contacts with multinational customers but not with the presence of multinationals in the same industry" (Smarzynska, 2004, p. 7). Subsequently, Arnold, Javorcik and Mattoo (2007) explored the situation in the manufacturing sector in the Czech Republic, where they researched the effects of services liberalization with the use of firm-level data for the period 1998-2003. In particular they examined the link between services sector reforms and the productivity of domestic firms in downstream manufacturing. Their study reached 
two conclusions. They found that "services policy matters for the productivity of manufacturing firms relying on services inputs" and "there is evidence that opening services sectors to foreign providers is a key channel through which services liberalization contributes to improved performance of downstream manufacturing sectors" (Arnold, Javorcik and Mattoo, 2007). Havranek and Irsova (2011) concentrated on vertical spillovers from FDIs using meta-analysis. In their study exploring 47 countries they found that there is "robust evidence consistent with knowledge transfer from foreign investors to domestic firms in supplier sectors" (Havranek and Irsova, 2011). Irsova and Havranek (2013) explore determinants of horizontal spillovers from FDI. Using a large sample of 1,205 spillovers around the world the authors found that the extent of positive spillover: "The nationality of foreign investors is essential: when the technology gap of domestic firms with respect to foreign investors is too large, horizontal spillovers are small."

Moreover, spillovers are likely to be smaller with higher trade openness and better protection of intellectual property rights in the host country. On the other hand, higher levels of human capital in the host country are associated with larger spillovers. Finally, investment projects in the form of joint ventures with domestic firms bring more positive spillovers than fully foreign-owned projects (Irsova and Havranek, 2013).

Similarly, like any investment, FDI has its lifecycle. After the initial period of growth followed by FDI inflow, the investment reaches maturity, which will be naturally followed by decline. At the maturity stage, the investment generates the highest cash flows. So it depends whether the venture decides to continue in operations or not. The decline can be slowed down by timely introduction of innovation. A different situation occurs when the foreign company repatriates the profits generated in the host country and leaves. In this case the money will leave the country. It remains a question, whether the host country has created enough potential for favourite conditions for innovations itself.

The profitability of Life cycle of FDI in the Czech Republic was studied by Novotny (2018), who researched the profitability life cycle of FDI on a panel of both advanced and emerging mostly European countries. For the Czech Republic the author found that "The first and the third scenario delimitate the likely future path of total FDI earnings... yearly total FDI earnings outflows will remain at levels above EUR $10 \mathrm{bn}$. (6\% of GDP) until 2018. They will then decrease and stabilize at around EUR 6 bn." After that in summary the author expects "FDI to continue to play an important role in determining the balance of payments in the Czech economy in the coming decades in spite of the fact that according to our baseline scenario the economy will record only a very gradual increase in new green or brown-field FDI inflows" (Novotny, 2018, pp. 1632-1633). Recent facts about FDI in the country in comparison with V4 provided Szabo (2019), who delivered an analysis of foreign direct investment in the Czech Republic since the 1990s to 2019 and concluded that: "As the ratio of the FDI stock to GDP has grown six-fold since 
1993, FDI has become a major contributor to the country's development. The authors suggest that "traditional incentives provided for FDI such as tax reliefs, tax breaks, and cash grants should be provided in a way that does not discourage domestic entrepreneurs to invest in their own country and ensure tax transparency, fairness and compliance with state aid regulations" (Szabo, 2019, p. 11).

\subsection{Human Capital and Growth}

Development and implementation of IFRS on accounting in the Czech Republic were researched among others by Sucher and Jindrichovska (2004), Nerudova and Bohusova (2008), Procházka (2010), Procházka and Ilinitchi (2011), Jindrichovska and Kubickova (2016), Procházka (2017; 2018) and Ugurlu and Jindřichovská (2019) who studied the relationship between import-export and IFRS in the Czech Republic using gravity model to see whether there is a correspondence between use of IFRS and country export and import

In their early study, Procházka and Ilinitchi (2011) suggest that different pattern of raising capital by companies across countries requires a more sophisticated approach to detect properly the influence of the IFRS adoption on mutual relation of labour and capital. With reference to the literature cited above, we propose to refine the level of IFRS adoption in each country depending on the scope of companies, for which financial statements based on IFRS are relevant. E.g. ... "the amendment of Czech Act on accounting, which - from 2011 - allows certain non-listed companies to select the IFRS as the basis for the preparation of individual financial statements accepted for statutory purposes may have introduced a supportive factor boosting the inflow of foreign direct investments into the Czech Republic." For this reason, further analysis should not focus on the adoption of the IFRS by listed companies only, but the possibility to apply the IFRS by non-listed companies should be taken into account too. Procházka and Ilinitchi (2011 p. 94), however, this inflow is mainly in the form of FDI investment in major MNEs, e.g. in automotive and sales. Which is pulling smaller local companies as suppliers as one of the forms of spillover effect. These findings are also repeated in Procházka (2017) where the author argues that there is a positive link on the performance of subsidiaries. Furthermore he suggests, that a high-quality IFRS adoption in a chain "foreign parent-local subsidiary" may positively affect an undeveloped accounting practice in a transition country if the number of such subsidiaries is significant.

\section{Data and Model}

\subsection{Czech FDI Inflow and FDI Outflow Some Background Information}

The biggest volume of inward FDIs came to the Czech Republic in the early 1990s. Nowadays the Czech enterprises are intertwined with foreign companies - about 85 percent of operations are owned by foreign enterprises, the majority of which come from Europe and less than five percent come from outer countries. 
FDI inflow and FDI outflow to and from the Czech Republic are shown in Figures 1 and 2.

Figure 1: FDI Inflow by Countries

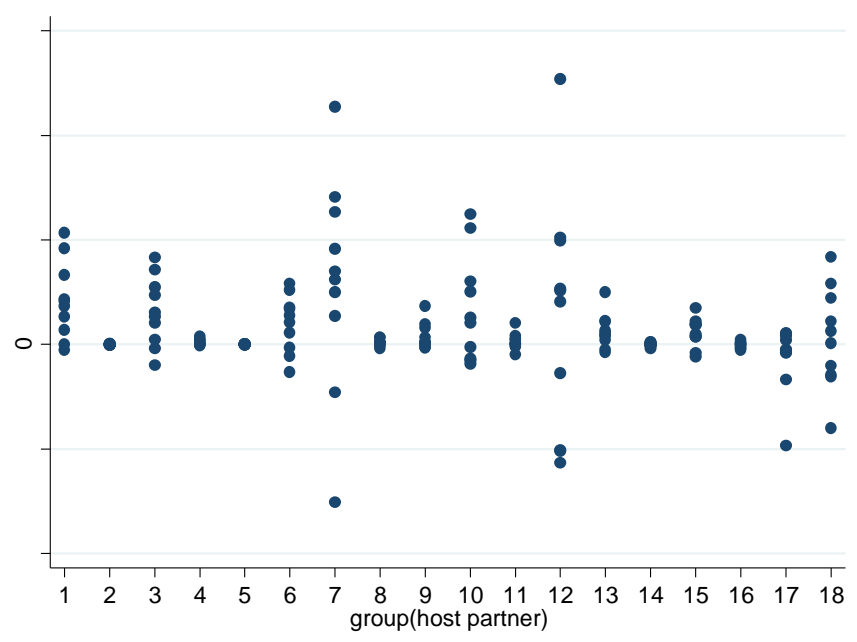

Source: Own elaboration using data from the Czech National Bank.

Notes: 1. Austria 2. Bulgaria 3. Cyprus 4. Denmark 5. Estonia 6. France 7. Germany 8. Hungary 9. Italy 10. Luxembourg 11. Malta 12. Netherlands 13. Poland 14. Romania 15. The Slovak Republic 16. Slovenia 17. Spain 18. United Kingdom.

Figure 2: FDI Outflow by Countries

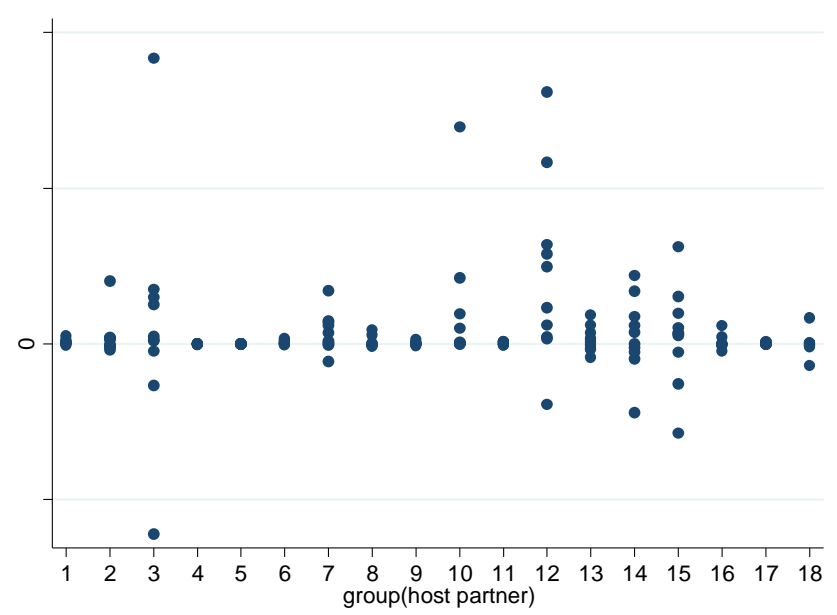

Source: Own elaboration using data from the Czech National Bank.

Notes: 1. Austria 2. Bulgaria 3. Cyprus 4. Denmark 5. Estonia 6. France 7. Germany 8. Hungary 9. Italy 10. Luxembourg 11. Malta 12. Netherlands 13. Poland 14. Romania 15. The Slovak Republic 16. Slovenia 17. Spain 18. United Kingdom. 
As it can be seen the major FDI to the Czech Republic came from Germany, and Netherlands and to lesser extent from Luxembourg, Austria, and the UK. Investment by MNCs from the EU has continuously stayed above $85 \%$ of all FDI in the country (Szabo, 2019). The main motivation for foreign companies to invest in the Czech Republic was its favorable investment climate and the high return on investments - above 10 percent. The country has provided one of the highest FDI rates of return in the EU At 13.04\% the Czech Republic had the highest return on FDI in the EU in 2015 (OECD, 2017). As to FDI Outflow, the biggest share has Cyprus and Netherlands, Luxembourg, and the Slovak Republic.

\subsection{Data Issues}

For our measurement, we collected 25 European Union member countries ${ }^{4}$ data that have bilateral FDI with the Czech Republic. In the data set we used, there are many zero values for inward and outward FDI. We deleted the countries which have more than five zero values in these variables; in other words if any country has no inward or outward FDI more than five years we removed the country. Thus Belgium, Finland, Greece, Latvia, Lithuania, Portugal are omitted. We analyze a panel of bilateral FDI for 19 EU countries (with the Czech Republic) over the period 20082017. We use the gravity model which is originated from the "Law of Universal Gravitation" by Isaac Newton in 1968 and adopted its formulation to trade (Muratoglu, Ugurlu and Muratoglu, 2017).

In the gravity model literature, an imported issue is discussed for this version of the data; zero trade problem. In the gravity model literature, if there is no trade or trade value is zero between two countries for a year, it is called a zero trade problem. Generally, in gravity models variables are used after taking their logarithms, therefore because the log of zero is not defined zero trade flows will be dropped (WTO, 2012).

WTO (2002) argues several ways to solve this, three different approaches to handle this problem: truncating the sample by dropping the observations with zero trade (Van Bergeijk and Oldersma, 1990; Wang and Winters, 1991; Raballand 2003) use this approach adding a small constant to zero values then taking their logarithms and estimating the model in levels. However, if second and third approaches are used, OLS estimation will not be correct. Therefore two techniques are suggested to use in these two approaches; using a Tobit estimator (Rose, 2004; Soloaga and Winters, 2001; Anderson and Marcouiller, 2002) and using Pseudo Poisson maximum likelihood (PPML) estimator. Comparing appropriates of these two techniques "Tobit model is not the appropriate model to explain why some trade flows are

\footnotetext{
${ }^{4}$ Austria, Bulgaria, Cyprus, Denmark, Estonia, Finland, France, Germany, Greece, Hungary, Israel, Italy, Latvia, Lithuania, Luxembourg, Malta, Netherlands, Poland, Portugal, Romania, Slovak Republic, Slovenia, Spain, Sweden, United Kingdom.
} 
missing" (Linders and de Groot, 2006) and in the presence of heteroskedasticity, the PPML is a robust approach (Santos Silva and Tenreyro, 2006). Baltagi, Egger and Pfaffermayr (2014) link the zero trade problem with trade relations of the countries. Small countries may not have trade relations with all possible trade partner countries. Although we investigate FDI data in this paper, we have zero values for bilateral trade, both FDI inward and FDI outward have zero values. Therefore we have a certain version of zero trade problem, and to solve this we will use the PPML model.

Procházka and Ilinitchi (2011), Gordon, Loeb and Zhu (2012), Lungu, Caraiani and Dascălu (2017), Chen, Ding and Xu (2011), Nejad et al. (2018), Baltagi, Egger and Pfaffermayr (2014), Beneish, Miller, and Yohn (2015) are the latest papers which used PPML model to overcoe the zero trade problem. Whereas Busse, Könniger, and Nunnenkamp (2010) do not use IFRS dummy it is convenient paper to understand the relationship between macroeconomic variables and FDI. Procházka and Ilinitchi (2011) is a theoretical paper, Busse, Könniger and Nunnenkamp (2010) use "gravity-type model", PPML and GMM estimation, Gordon, Loeb, and Zhu, (2012) use OLS and instrumental variable model, Lungu, Caraiani and Dascălu (2017) use OLS model, Nejad et al. (2018) use Square Dummy variable biascorrected (LSDVC) model, and Beneish, Miller, and Yohn (2015) use OLS model.

Except Charles, Ding and $\mathrm{Xu}$ (2011) these papers do not use any distance variable, therefore we can say that they do not think that a distance has impact on Visegrad FDIs. Some of these papers use FDI inflow some of use FDI outflow variable as an independent variable. Charles, Ding and $\mathrm{Xu}$ (2011) use summation of the absolute values of FDI flows and FDI outflows as a different approach for a dependent variable. Moreover, independent variables in these papers are various. Table 1 shows independent variables of the selected papers and their significance, and direction of the coefficients.

Table 1: Result of Selected Variables for Selected Papers

\begin{tabular}{|c|c|c|c|c|c|}
\hline Model: & $1^{a}$ & $2^{b}$ & $3^{c}$ & $4^{d}$ & 5 \\
\hline $\begin{array}{l}\text { Variable } \\
\text { Coefficient }\end{array}$ & $\begin{array}{l}\text { lnGDP } \\
\text { sig. /pos. }\end{array}$ & $\begin{array}{c}\text { SIZE } \\
\text { not sig. }\end{array}$ & $\begin{array}{l}\log \text { GDP } \\
\text { sig./pos. }\end{array}$ & $\begin{array}{c}\text { GDPi } \\
\text { sig./pos. }\end{array}$ & $\begin{array}{c}\text { GDPGROWTH } \\
\text { sig./pos }\end{array}$ \\
\hline $\begin{array}{l}\text { Variable } \\
\text { Coefficient }\end{array}$ & $\begin{array}{c}\ln (\text { DiffGDPC) } \\
\text { not sig. }\end{array}$ & $\begin{array}{l}\text { GDPCAP } \\
\text { not sig. }\end{array}$ & $\begin{array}{l}\text { GDP_CAP } \\
\text { sig./neg. }\end{array}$ & $\begin{array}{c}\text { GDPj } \\
\text { sig./pos. }\end{array}$ & $\begin{array}{l}\text { Inflation } \\
\text { sig./pos }\end{array}$ \\
\hline $\begin{array}{l}\text { Variable } \\
\text { Coefficient }\end{array}$ & $\begin{array}{l}\text { Growth } \\
\text { sig. /pos. }\end{array}$ & $\begin{array}{l}\text { GDPG } \\
\text { sig./pos. }\end{array}$ & $\begin{array}{l}\text { GDP_GR } \\
\text { not sig. }\end{array}$ & $\begin{array}{c}\text { DIST } \\
\text { sig./neg. }\end{array}$ & $\begin{array}{l}\text { EXCH } \\
\text { not sig }\end{array}$ \\
\hline $\begin{array}{l}\text { Variable } \\
\text { Coefficient }\end{array}$ & $\begin{array}{c}\ln \text { (inflaton) } \\
\text { not sig. }\end{array}$ & $\begin{array}{r}\text { OPEN } \\
\text { not sig. }\end{array}$ & $\begin{array}{l}\text { INTEREST } \\
\text { sig. /neg. }\end{array}$ & $\begin{array}{l}\text { GDPPCi } \\
\text { not sig. }\end{array}$ & $\begin{array}{c}\text { EDU } \\
\text { sig./pos }\end{array}$ \\
\hline $\begin{array}{l}\text { Variable } \\
\text { Coefficient }\end{array}$ & $\begin{array}{l}\text { Openness } \\
\text { sig. /neg. }\end{array}$ & $\begin{array}{c}\text { EXCHAN } \\
\text { GE } \\
\end{array}$ & $\begin{array}{c}\text { EXCHANGE } \\
\text { sig. /neg. }\end{array}$ & $\begin{array}{l}\text { GDPPCi } \\
\text { not sig. }\end{array}$ & $\begin{array}{l}\text { NODA } \\
\text { not sig }\end{array}$ \\
\hline $\begin{array}{l}\text { Variable } \\
\text { Coefficient }\end{array}$ & $\begin{array}{c}\text { BIT } \\
\text { sig./pos. }\end{array}$ & $\begin{array}{c}\text { INTEREST } \\
\text { not sig. }\end{array}$ & $\operatorname{GOV}_{\bar{X}}$ & - & - \\
\hline $\begin{array}{l}\text { Variable } \\
\text { Coefficient }\end{array}$ & $\begin{array}{c}\text { RTA } \\
\text { sig. /pos. }\end{array}$ & $\begin{array}{c}\text { IFRS:ADO } \\
\text { PT }\end{array}$ & $\begin{array}{c}\text { IFRS: IFRSsd } \\
\text { sig./pos. }\end{array}$ & $\begin{array}{c}\text { IFRS:CONFO } \\
\text { RM }\end{array}$ & $\begin{array}{c}\text { IFRS } \\
\text { sig./pos }\end{array}$ \\
\hline
\end{tabular}


Notes: 1: Busse, Könniger and Nunnenkamp, 2010 2: Gordon, Loeb and Zhu, 2012 3: Lungu, Caraiani and Dascălu, 2017 4: Chen, Ding and Xu 2011 5: Nejad et al. (2018) a: Model 1 in the paper b:Developed countries. c: EU countries d: Model 6.1. in the model. E: Model 2 in the paper. sig: significant, pos: positive, neg: negative BIT : Bilateral investment treaty RTA: Dummy regional trade agreement, GDP: Real GDP, DiffGDPC: Difference between source and host countries' GDP per capita, Growth: Real GDP growth rate of host country in percent, Openness: Sum of imports and exports in percent of GDP (host country), SIZE: Log of GDP in current US dollars, capturing a market factor that attracts FDI. GDPCAP and GDP_CAP: GDP per capita in current US dollars scaled by 1000, capturing a labor cost factor that attracts FDI. GDPG: GDP growth measured by dividing normal GDP with current year population, capturing a market factor that attracts FDI. OPEN: Absolute value of exports plus imports as percentage of real GDP, capturing an investment climate factor that attracts FDI. PHONE: Mobile cellular subscription per 100 people, capturing infrastructure element that attracts FDI, EXCHANGE, and EXCH: Annual year-end exchange rates measured by national currency units per SDRb scaled by 100, capturing an investment climate factor that attracts FDI. INTEREST: National lending interest rates measured by the period average in percentage per annual year. GDP_GR :Annual percentage growth rate of GDP per capita based on constant local currency. INTEREST: Lending rate is the bank rate, GOV_INDEX: Governance index, NODA: Natural Logarithm of Net official development assistance.

Table 1 shows that Gordon, Loeb, and Zhu (2012) estimate model for developed and developing economies and find that there is a positive relationship between IFRS adoption and FDI inflows. Beneish, Miller, and Yohn (2015) investigate the effect of IFRS on debt, foreign equity, and FDI and found similar results with Gordon, Loeb, and Zhu (2012) in terms of FDI.

\section{Results}

Based on the literature above we decide to use the sum of FDI inflow and FDI outflow (FDI inflow+FDI outflow) as a dependent variable ${ }^{5}$ mostly based on Charles, Ding and $\mathrm{Xu}$ (2011). Because if we estimate gravity model, the dependent variables are GDP of the Czech Republic (GDP_h), GDP of the partner countries (GDP_p), distance between the countries (DIST), the population of the Czech Republic (POP_h), population of the partner countries (POP_p),

We use some dummy variables these variables are IFRS dummy (IFRS), Border dummy (border) and Visegrad dummy (VIS). See Appendix I for the definitions of dummy variables. Except for dummy variables, GDP, population data were collected from the World Bank World Development Indicators database and distance between the countries from CEPII. FDI data were collected from the Czech National Bank. Dummy variables were calculated by authors. We estimate the PPML model because of the zero trade problem that was mentioned above. The estimated regression model is:

5If any variable is missing we wrote " 0 " for the respective cell. 


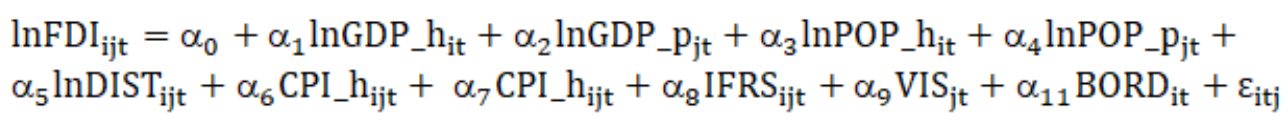

where $i=1$ and shows the host country and $j=1$ to 19 and shows partner countries, $\varepsilon_{i t j}$ shows the error term. We use the logarithm of the variables except for CPI, because CPI values are ratio values, thus they have not big variation comparing to other variables. Definition and descriptive statistics of the variables and the correlation coefficients are provided in the appendix.

According to the dependent variables of the models, we estimated three different models. The dependent variables are lninflow, lnoutflow and lnFDI which is calculated as logarithm of sum of FDI inflow and FDI outflow. In the first model GDP of partner country, population of the host country, distance, CPI of host and partner country and Visegrad and border dummy are significant.

Thus, the model results show that FDI inflow of the Czech Republic is positively affected by partner country GDP and its own population and CPI, distance. However partner countries CPI a distance have negative effect on FDI inflow of Czech Republic. The second model; only Czech Republic CPI and Border dummy are statistically significant and positively affected. In the last model we nearly have same results with the first model. In the third model with aggregated FDI independent variable, IFRS is significant and positive. Therefore there is a positive relationship between IFRS and FDI accumulations in Czech Republic; in other words, IFRS usage has been increased the total FDI accumulation of the country. On the other hand GDP of partner country, CPI of the host country, being Visegrad country, having a border increase FDI among the countries. The population of partner country and CPI of the partner country negatively affected the FDI.

Table 2: PPML Models

\begin{tabular}{|c|c|c|c|c|c|c|}
\hline \multirow[b]{2}{*}{ Variable } & \multicolumn{2}{|c|}{ Dependent Var.: Ininflow } & \multicolumn{2}{|c|}{$\begin{array}{c}\text { Dependent Var.: } \\
\text { lnoutflow }\end{array}$} & \multicolumn{2}{|c|}{ Dependent Var. : InFDI } \\
\hline & Coefficient & p value & Coefficient & p value & Coefficient & p value \\
\hline InGDP_h & 0.434702 & 0.75 & 1.031975 & 0.607 & 1.880138 & 0.166 \\
\hline InGDP_p & $0.32154 * * *$ & 0.000 & 0.166487 & 0.339 & $0.264269 * * *$ & 0.000 \\
\hline InPOP_h & $0.089818 * *$ & 0.028 & 0.03295 & 0.624 & 0.052461 & 0.153 \\
\hline InPOP_p & -26.9943 & 0.483 & -48.3525 & 0.202 & $-72.4227 * *$ & 0.017 \\
\hline InDIST & $-0.29562 * * *$ & 0.000 & -0.16585 & 0.341 & $-0.25823 * * *$ & 0.000 \\
\hline CPI_h & $0.105865^{*}$ & 0.072 & $0.14763 * *$ & 0.024 & $0.158223 * * *$ & 0.004 \\
\hline CPI_p & $-0.06484 * * *$ & 0.000 & -0.04549 & 0.192 & $-0.057 * *$ & 0.018 \\
\hline IFRS & 0.284814 & 0.168 & 0.176615 & 0.472 & $0.386355^{*}$ & 0.075 \\
\hline VIS & $0.472494 * * *$ & 0.001 & 0.044395 & 0.846 & $0.3285 * *$ & 0.01 \\
\hline BORD & $0.222904 * *$ & 0.029 & $0.377354 * *$ & 0.009 & $0.293041 * * *$ & 0.000 \\
\hline Constant & 418.3856 & 0.501 & 743.8883 & 0.211 & $1110.035 * *$ & 0.023 \\
\hline R-sq. & \multicolumn{2}{|c|}{0.1688} & \multicolumn{2}{|c|}{0.1240} & \multicolumn{2}{|c|}{0.1831} \\
\hline Obs. & \multicolumn{2}{|c|}{180} & \multicolumn{2}{|c|}{180} & \multicolumn{2}{|c|}{180} \\
\hline
\end{tabular}

Note: $* * *$ and $* * *$ shows $\% 10, \% 5$ and $\% 1$ level significance respectively. 


\section{Conclusion, Limitations and Avenues for Further Research}

In this paper, we explored the impact of traditional macroeconomic variables on foreign direct investment in the Czech Republic with the use of two specifications of the gravity model. We have found that gravity model works for FDI in the Czech Republic, albeit the IFRS dummy representing change of accounting environment show as significant under model with the sum of inward and outward. In light of previous literature in this area we suggest that better specification is needed, or a change in approach - not to explore the IFRS in isolation of only one country. In case of Foreign Direct Investment, we expect that the links between investing and recipient countries will be stronger creating room for long term working relationship from an institutional or economic standpoint because we can perceive long term engagement on both sides and not just a short term action or one-of trading operation. Also, in particular case of multinational companies, the recipient country must offer to the investing party more opportunities than provide comparative home investment opportunities.

Institutional background provided by the country is important to attract the FDIs, however since there is already big proportion of foreign companies in place in the Czech Republic the influence of new FDIs will not be so easy to capture and different specifications talking into account more qualitative features would be recommended see e.g. Nejad et al. (2018). It would also be interesting to concentrate on the effect of FDI spillovers and impact of FDIs in specific sectors of the economy.

New institutional change is a result of coercive and normative pressures and leads to greater isomorphism with the institutional framework of surrounding European economies thus enabling more flexible and operational trade relations with positive impact on effectiveness of FDIs in the Czech Republic. Currently, there is a new accounting act in preparation that will institute compulsory IFRS adoption in all Czech companies. Therefore it will be interesting to analyze the situation in a few years time to explore the state of normative isomorphism.

\section{References:}

Albu, C.N., Albu, N., Pali-Pista, S.F., Gîrbină, M.M., Selimoglu, S.K., Kovács, D.M., Lukács, J. , Mohl, G., Müllerová, L., Paseková, M., Arsoy, A.P., Sipahi, B., Strouhal, J. 2013. Implementation of IFRS for SME s in Emerging Economies: Stakeholder Perceptions in the Czech Republic, Hungary, Romania and Turkey. Journal of International Financial Management \& Accounting, 24(2), 140175.

Albu, N. 2013. Exploring the recent evolution of the accounting profession in Romania-an institutional approach. Accounting and Management Information Systems, 12(4), 537-552. 
Albu, N., Albu, C.N. 2014. IFRS application in Central and South-Eastern European countries. Accounting \& Management Information Systems, 13(2), 182-197.

Anderson, J.E., Marcouiller, D. 2002. Insecurity and the Pattern of Trade: An Empirical Investigation. Review of Economics and Statistics, 84, 342-352.

Arnold, J., Javorcik, B.S., Mattoo, A. 2007. Does services liberalization benefit manufacturing firms? Evidence from the Czech Republic. The World Bank.

Babuněk, O. 2012. Foreign direct investment in Visegrad four and the main trading partners. Statistika: Statistics and Economy Journal, 49(4), 14-26.

Badi, H., Baltagi, B., Egger, P., Pfaffermayr, M. 2014. Panel Data Gravity Models of International Trade. CESifo Working Paper Series 4616, CESifo Group Munich.

Beneish, M.D., Miller, B.P., Yohn, T.L. 2015. Macroeconomic evidence on the impact of mandatory IFRS adoption on equity and debt markets. Journal of Accounting and Public Policy, 34, 1-27. doi:10.1016/j.jaccpubpol.2014.10.002.

Busse, M., Königer, J., Nunnenkamp, P. 2010. FDI promotion through bilateral investment treaties: More than a BIT? Review of World Economics, 146, 147-177.

Chen, C.J., Ding, Y., Xu, B. 2014. Convergence of accounting standards and foreign direct investment. The International Journal of Accounting, 49(1), 53-86.

DiMaggio, P., Powell, W. 1983. The iron cage revisited: Institutional Isomorphism and Collective Rationality in Organizational Fields. American Sociological Review, 48, 147-160.

DiMaggio, P., Powell, W. 1991. The New Institutionalism in Organizational Analysis. Chicago: University of Chicago Press.

Efobi, U., Nnadi, M., Odebiyi, J., Beecroft, I. 2014. Do the Rules Attract the Money? Implication of IFRS Adoption on Foreign Direct Investment. Implication of IFRS Adoption on Foreign Direct Investment, June 30.

Fontagné, L. 1999. Foreign Direct Investment and International Trade: Complements or Substitutes? OECD Science, Technology and Industry Working Papers, No. 1999/03, OECD Publishing, Paris, https://doi.org/10.1787/788565713012.

Gordon, L.A., Loeb, P.M., Zhu, W. 2012. The impact of IFRS adoption on foreign direct investment. Journal of accounting and public policy, 31(4), 374-398.

Havranek, T., Irsova, Z. 2011. Estimating vertical spillovers from FDI: Why results vary and what the true effect is. J. Int. Econ., 85, 234-244.

Irsova, Z., Havranek, T. 2013. Determinants of horizontal spillovers from FDI: Evidence from a large meta-analysis. World Dev., 42, 1-15.

Jindrichovska, I., Kubickova, D. 2016. Economic and Political Implications of IFRS Adoption in the Czech Republic. In Uchenna, E., Nnadi, M., Tanna, S., Iyoha, F., Economics and Political Implications of International Financial Reporting Standards (105-132). Hershey, PA: IGI Global. doi:10.4018/978-1-466-9876-5.

Judge, W., Li, S., Pinsker, R. 2010. National adoption of international accounting standards: An institutional perspective. Corporate Governance: An International Review, 18(3), 161-174.

Linders, G.M. and de Groot, H.L. 2006. Estimation of the gravity equation in the presence of zero flows. Tinbergen Institute Discussion Paper, 072/3.

Liu, C., Yao, L.J., Hu, N., Liu, L. 2011. The impact of IFRS on accounting quality in a regulated market: An empirical study of China. Journal of Accounting, Auditing and Finance, 26(4), 659-676.

Lungu, C.I., Caraiani, C., Dascălu, C. 2017. The impact of IFRS adoption on foreign direct investments: Insights for emerging countries. Accounting in Europe, 14(3), 331-357. 
MacGregor Pelikánová, R. 2017. European Myriad of Approaches to Parasitic Commercial Practices. Oeconomia Copernicana, 8(2), 167-180. Doi: 10.24136/oc.v8i2.11.

MacGregor Pelikánová, R. 2019. Harmonization of the protection against misleading commercial practices: ongoing divergences in Central European countries. Oeconomia Copernicana, 10(2), 239-252.

Maitah, M., Hayat, A., Malec, K., Eldeeb, O. 2014. The impact of foreign direct investments on employment in the Czech Republic. Research Journal of Applied Sciences, 9(12), 1001-1008.

Márquez-Ramos, L. 2011. European accounting harmonization: Consequences of IFRS adoption on trade in goods and foreign direct investments. Emerging markets finance and trade, 47(sup4), 42-57.

Miteski, M., Stefanova, D.J. 2017. The Impact of Sectorial FDI on Economic Growth in Central, Eastern and Southeastern Europe (No. 1/2017). Working Paper.

Muratoğlu, G., Uğurlu, E., Muratoğlu, Y. 2017. Trade Flows between Russia and Other Black Sea Economic Cooperation Countries: A Gravity Model Analysis. GUEJISS, Gümüşhane University Electronic Journal of The Institute of Social Sciences, 8(20), 287-307.

Nejad, M.Y., Ahmad, A., Mdsalleh, F., Rahim, R.A. 2018. IFRS adoption and foreign direct investment: An application of the LSDVC estimator. Proceeding of the 5th International Conference on Management and Muamalah (ICoMM 2018) e-ISBN: 978-967-2122.

Nerudova, D., Bohusova, H. 2008. The empirical study of the SMEs position in the process of IFRS for SME application in the Czech Republic. Economics and Management, 163-169.

Novotný, F. 2018. Profitability Life Cycle of Foreign Direct Investment: Application to the Czech Republic, Emerging Markets Finance and Trade, 54(7), 1623-1634, DOI: 10.1080/1540496X.2017.1316259.

OECD. 2017. Czech Republic Trade and Investment Statistical Note, OECD, Paris, available at http://www.oecd.org/investment/Czech-Republic-trade-investmentstatistical-country-note.pdf.

Okpala, K.E. 2012. Adoption of IFRS and financial statements effects: The perceived implications on FDI and Nigeria economy. Australian Journal of Business and Management Research, 2(5), 76.

Phan, D.H.T., Joshi, M., Mascitelli, B. 2016. International Financial Reporting Standards (IFRS) adoption in Vietnam: from isolation to isomorphism. In Economics and Political Implications of International Financial Reporting Standards, 266-281.

Procházka, D.A. 2010. The development of financial and management accounting after the IFRS adoption: a case from the Czech Republic. Available at SSRN 1660122.

Procházka, D., Procházková Ilinitchi, C. 2011. The theoretical relationships among foreign direct investments, migration and IFRS adoption. European Financial and Accounting Journal, 6(4), 1-15.

Procházka, D. 2017. Forced IFRS Adoption: Direction of the "EU-15 ParentsCEESubsidiaries" Links. In New Trends in Finance and Accounting. Švýcarsko, Springer International Publishing, 361-371.

Procházka, D. 2018. Financial Performance of Czech Subsidiaries of the EU-Listed Companies. In: Procházka D. (eds.) The Impact of Globalization on International Finance and Accounting. Springer Proceedings in Business and Economics. Springer, Cham. 
Raballand, G. 2003. Determinants of the Negative Impact of Being Landlocked on Trade: An Empirical Investigation through the Central Asian Case, Comparative Economic Studies, 45, 520-536.

Rose, A.K. 2000. One Money, One Market: The Effect of Common Currencies on Trade, Economic Policy, 15, 8-45.

Silva, S.J.,Tenreyro, S. 2006. The log of gravity. The Review of Economics and Statistics, 88, 641-658.

Soloaga, I., Winters, A.L. 2001. Regionalism in the Nineties: What Effect on Trade? North American Journal of Economics and Finance, 12, 1-29.

Szabo, S. 2019, FDI in the Czech Republic: A Visegrád Comparison, European Economy, Economic and Financial Affairs, ISSN 2443-8030 (online)Septimiu Szabo Economic Brief 042, February, https://ec.europa.eu/info/publications/economic-andfinancial-affairs-publications_en.

Smarzynska Javorcik, B. 2004. Does foreign direct investment increase the productivity of domestic firms? In search of spillovers through backward linkages. American economic review, 94(3), 605-627.

Sucher, P., Jindrichovska, I. 2004. Implementing IFRS: A case study of the Czech Republic. Accounting in Europe, 1(1), 109-141.

Thalassinos, I.E. and Kiriazidis, T. 2003. Degrees of Integration in International Portfolio Diversification: Effective Systemic Risk. European Research Studies Journal, 6(12), 119-130.

Thalassinos, I.E. and Stamatopoulos, V.T. 2015. The Trilemma and the Eurozone: A PreAnnounced Tragedy of the Hellenic Debt Crisis. International Journal of Economics and Business Administration, 3(3), 27-40.

Thalassinos, I.E. 2008. Trends and Developments in the European Financial Sector. European Financial and Accounting Journal, 3(3), 44-61.

Ugurlu, E., Jindrichovska, I. 2019. Estimating Gravity Model in the Czech Republic: Empirical Study of Impact of IFRS on Czech International Trade. European Research Studies Journal, 22(2), 265-281.

Uğurlu, E. 2010. Growth And Openness Relationship in the EU15: Panel Data Analysis. Ekonomika, 89(2), 44-54. doi: 10.15388/Ekon.2010.0.986.

Van Bergeijk, P.A.G., Oldersma, H. 1990. Detente, Market-Oriented Reform and German Unification: Potential Consequences for the World Trade System, Kyklos, 43, 599609.

Wang, Z.K., Winters, A.L. 1991. The Trading Potential of Eastern Europe. CEPR Discussion Paper, no. 610, London.

Wysocki, P. 2011. New institutional accounting and IFRS. Accounting and business research, 41(3), 309-328.

WTO. 2012. World Trade Organisation: A Practical Guide to Trade Policy Analysis. WTO Publications. ISBN 978-92-870-3812-8.

APPENDIX:

Table 1a: List of explanatory variables

\begin{tabular}{|l|l|l|}
\hline Abbreviation & Definition & Source \\
\hline INFLOW & $\begin{array}{l}\text { Yearly FDI inflows to Czech Republic from } \\
\text { each partner country, (BoP, current US\$) }\end{array}$ & Czech National Bank \\
\hline OUTFLOW & $\begin{array}{l}\text { Yearly FDI outflows from the Czech Republic } \\
\text { to each partner country, (BoP, current US\$) }\end{array}$ & Czech National Bank \\
\hline
\end{tabular}




\begin{tabular}{|l|l|l|}
\hline GDP_H & $\begin{array}{l}\text { Host (Czech Republic) Country Gross Domestic } \\
\text { Product (Purchaser's prices, constant 2010 } \\
\text { US\$) }\end{array}$ & World Bank, WDI \\
\hline GDP_P & $\begin{array}{l}\text { Partner Country Gross Domestic Product } \\
\text { (Purchaser's prices, constant 2010 US\$) }\end{array}$ & World Bank, WDI \\
\hline POP_H & Host Country Population & World Bank, WDI \\
\hline POP_P & Partner Country Population & World Bank, WDI \\
\hline CPI_h & Host Country Consumer Price Index & World Bank, WDI \\
\hline CPI_p & Partner Country Consumer Price Index & World Bank, WDI \\
\hline DIST & Distance Between Countries (km) & CEPII \\
\hline BORD ${ }^{\text {a }}$ & $\begin{array}{l}\text { Border Dummy: 1 if the country has a border } \\
\text { with the Czech Republic and 0 for others }\end{array}$ & Authors' Calculation \\
\hline VIS ${ }^{b}$ & $\begin{array}{l}\text { Visegrad(V4) Dummy: 1 for Visegrad } \\
\text { countries and 0 for others }\end{array}$ & Authors' Calculation \\
\hline IFRS & $\begin{array}{l}\text { IFRS Dummy: 1 if the year is 2010 and after } \\
\text { and 0 for others }\end{array}$ & Authors' Calculation \\
\hline
\end{tabular}

Notes: a: Austria, Germany, Poland, and the Slovak Republic. b: Hungary, Poland, Slovak

Table 2a: Descriptive statistics

\begin{tabular}{|l|l|l|l|l|l|l|}
\hline & mean & mean & sd & range & $\min$ & $\max$ \\
\hline gdp_h & $2.16 \mathrm{E}+11$ & $2.12 \mathrm{E}+11$ & $1.16 \mathrm{E}+10$ & $3.84 \mathrm{E}+10$ & $2.03 \mathrm{E}+11$ & $2.41 \mathrm{E}+11$ \\
\hline gdp_p & $8.42 \mathrm{E}+11$ & $2.65 \mathrm{E}+11$ & $1.11 \mathrm{E}+12$ & $3.86 \mathrm{E}+12$ & $8.44 \mathrm{E}+09$ & $3.87 \mathrm{E}+12$ \\
\hline dist & 1785.093 & 905.5848 & 3516.813 & 15804.43 & 293.086 & 16097.52 \\
\hline outflow & 120941.3 & 4499.416 & 557373.7 & 6111900 & -2444218 & 3667683 \\
\hline inflow & 273125.7 & 38287.29 & 903644.3 & 8106147 & -3021403 & 5084744 \\
\hline Indist & 6.8741 & 6.8083 & 0.8581 & 4.0059 & 5.6804 & 9.6864 \\
\hline cpi_p & 104.7239 & 105.7648 & 5.367422 & 26.4163 & 89.2704 & 115.6868 \\
\hline cpi_h & 104.3782 & 106.0249 & 4.33039 & 13.31303 & 97.5542 & 110.8672 \\
\hline
\end{tabular}

Table 3a. Correlation Matrix

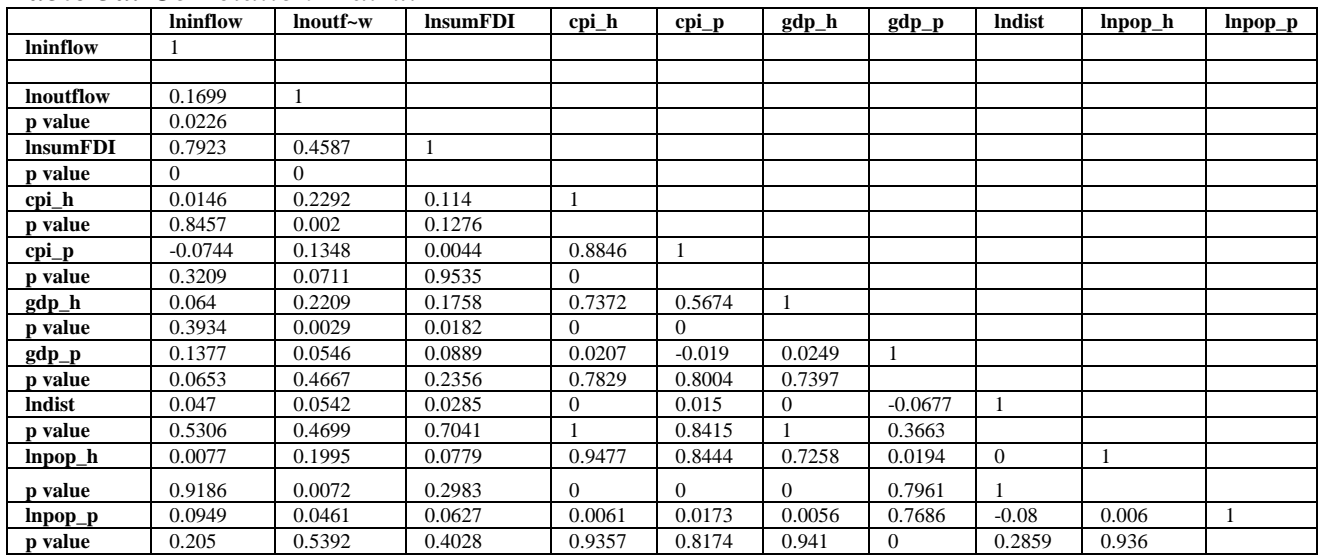

